\title{
Research Paper Suberoylanilide hydroxamic acid increases anti-cancer effect of tumor necrosis factor-a through up-regulation of TNF receptor 1 in lung cancer cells
}

\author{
Bo Ra You ${ }^{1}$, Bo Ram Han ${ }^{1}$, Woo Hyun Park ${ }^{1}$ \\ ${ }^{1}$ Department of Physiology, Medical School, Institute for Medical Sciences, Chonbuk National University, Jeonju, 561-180, \\ Republic of Korea
}

Correspondence to: Woo Hyun Park, email: parkwh71@chonbuk.ac.kr

Keywords: Iung cancer, histone deacetylase, suberoylanilide hydroxamic acid, tumor necrosis factor-a, apoptosis

Received: December 08, $2015 \quad$ Accepted: January 05, $2017 \quad$ Published: January 13, 2017

\section{ABSTRACT}

Suberoylanilide hydroxamic acid (SAHA) as a histone deacetylase (HDAC) inhibitor has anti-cancer effect. Here, we evaluated the effect of SAHA on HDAC activity and cell growth in many normal lung and cancer cells. We observed that the HDAC activities of lung cancer cells were higher than that of normal lung cells. SAHA inhibited the growth of lung cancer cells regardless of the inhibitory effect on HDAC. This agent induced a G2/M phase arrest and apoptosis, which was accompanied by mitochondrial membrane potential (MMP: $\Delta \Psi \mathrm{m}$ ) loss in lung cancer cells. However, SAHA did not induce cell death in normal lung cells. All tested caspase inhibitors prevented apoptotic cell death in SAHA-treated A549 and Calu-6 lung cancer cells. Treatment with tumor necrosis factor-alpha (TNF-a) enhanced apoptosis in SAHA-treated lung cancer cells through caspase- 8 and caspase- 9 activations. Especially, SAHA increased the expression level of TNF-a receptor 1 (TNFR1), especially acetylation of the region of TNFR1 promoter $-223 /-29$ in lung cancer cells. The down-regulation of TNFR1 suppressed apoptosis in TNF-a and SAHA-treated lung cancer cells. In conclusion, SAHA inhibited the growth of lung cancer cells via a G2/M phase arrest and caspasedependent apoptosis. SAHA also enhanced apoptotic effect of TNF-a in human lung cancer cells through up-regulation of TNFR1. TNF-a may be a key to improve anticancer effect of HDAC inhibitors.

\section{INTRODUCTION}

Histone deacetylase (HDAC) triggers the suppression of transcription by removal of acetyl groups from lysine amino acid on histones [1]. Many studies have been demonstrated that the expression of HDAC is upregulated in many human cancers [2-4]. Therefore, diverse HDAC inhibitors are being studied in various cancers [5-7]. Suberoylanilide hydroxamic acid (SAHA) is the first HDAC inhibitor approved by U.S. Food and Drug Administration for the treatment of cutaneous T-cell lymphoma. It also has been clinically tested in lung and gastrointestinal cancers [8-10]. Numerous evidences indicate that SAHA induces apoptosis and inhibits metastasis in various cancer cells $[11,12]$.

The tumor necrosis factor (TNF) family is composed of 19 ligands and 29 receptors. It can modulate inflammation, proliferation and apoptosis in the cells [13-16]. There are three major cytokines in TNF family, TNF- $\alpha$, TNF-related apoptosis-inducing ligand (TRAIL) and Fas ligand (FasL). TNF- $\alpha$ can bind two receptors, TNF receptor 1 (TNFR1) and TNF receptor 2 (TNFR2). When TNF- $\alpha$ binds to TNFR1, it induces caspase- 8 activation and then finally causes apoptosis [17]. TNF- $\alpha$ also activates NF- $\mathrm{kB}$ pathway and $\mathrm{AP}-1$ signaling via binding to TNFR2 [18]. TRAIL and FasL also lead to apoptosis mediated by their receptors [19]. TNF family cytokines can be a novel molecule because they sensitize cancer cells to the anti-cancer effect of HDAC inhibitor via induction of death receptor [20].

Lung cancer is the most common cancer and major cause of cancer death in the worldwide. The main types are small cell lung cancer (SCLC) and non-small cell lung cancer (NSLC). There are three subtypes of NSCLC, 
adenocarcinoma, squamous cell carcinoma and large cell carcinoma. The major cause of lung cancer are tobacco smoke and this environmental factor could increase the possibility of histone modification in lung cells [21]. Although SAHA has been tested clinically in lung cancer $[8,22]$, little is known about whether SAHA is a proper anti-cancer drug in lung cancer. Therefore, in this study, we investigated the effect of SAHA on HDAC activity and cell death, and suggested a promising combination strategy using TNF- $\alpha$ to improve anti-cancer effect of SAHA in lung cancer cells.

\section{RESULTS}

\section{Effects of SAHA on HDAC activities in normal lung and cancer cells}

Firstly, we measured the basal HDAC activities in normal lung and cancer tissues from patients. The HDAC activities of squamous cell carcinoma and large cell carcinoma were higher than that of normal and adenocarcinoma tissues (Figure 1A). In addition, stage III tissues of adenocarcinoma and large cell carcinoma showed low HDAC activities rather than stage I tissues of those (Figure 1A). It was also observed that Calu-6, NCI-H1299 and SCLC cells showed higher HDAC activities compared with normal lung and other lung cancer cells (Figure 1B).

Next, we treated with $5 \mu \mathrm{M}$ SAHA to normal lung and cancer cells. When we measured the HDAC activities in cytosol and nuclear fraction, SAHA significantly decreased the HDAC activities of nuclear fraction in Calu-6 and NCI-H69 cells (Figure 1C). However, this agent increased the cytosol and nuclear HDAC activities of some NSCLC cells (Figure 1C).

\section{Effects of SAHA on cell growth and cell death in normal lung and cancer cells}

SAHA did not alter the growth of normal lung, HSAEC, HBEC and HPF cells at 24 and 48 hours (Figure 2A-2C). However, SAHA inhibited the growth
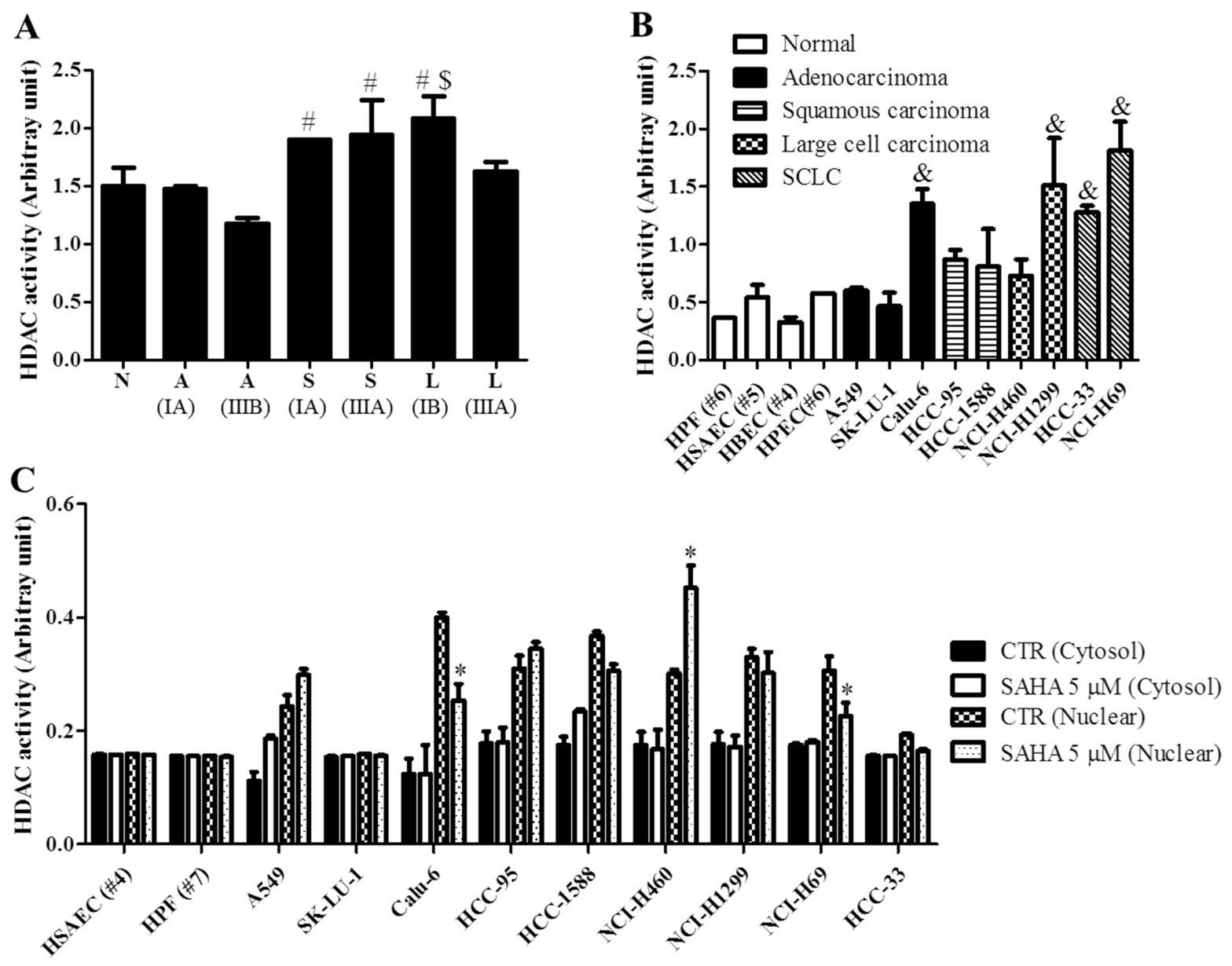

Figure 1: Effect of SAHA on HDAC activities in human normal lung and cancer cells. (A) and (B) Graphs show the basal HDAC activities of lung cancer patients (A), normal lung and cancer cells (B). (C) Graph shows the cytosol and nuclear HDAC activities in normal lung and cancer cells. ${ }^{\#} p<0.05$ compared with A ( I A). ${ }^{\$} p<0.05$ compared with A (III A). ${ }^{\star} p<0.05$ compared with HPF cells. $* p<0.05$ compared with SAHA-untreated control group. 
of lung cancer cells in dose and time-dependent manners at these times (Figure 2D-2L). Calu-6 cells were most sensitive to SAHA with an $\mathrm{IC}_{50}$ of $5 \mu \mathrm{M}$ at 24 hours (Figure 2F). The $\mathrm{IC}_{50}$ values of SAHA in A549, HCC-1588, NCI-H69, HCC-33 cells were approximately $20 \mu \mathrm{M}$ at 24 hours (Figure 2D, 2H, 2K, 2L). Although SK-LU-1, HCC-95, NCI-H460 and NCI-H1299 cells showed resistance to SAHA at 24 hours, SAHA dramatically decreased the growth of these cells at 48 and 72 hours (Figure 2E, 2G, 2I and 2J). This agent also inhibited normal lung cell growth at 72 hours (Figure 2A-2C). However, the susceptibility of lung cancer cells to SAHA was higher than that of normal lung cells at 72 hours.

When we analyzed the cell cycle phase in $5 \mu \mathrm{M}$ SAHA-treated normal lung and cancer cells, SAHA induced a G2/M phase arrest in NCI-H460 and Calu-6 cells at 24 hours (Figure $3 \mathrm{~A})$. In addition, we observed that this agent led to a G2/M phase arrest in A549, SK-LU-1, HCC-95, HCC-1588 and NCI-H1299 cells (Supplementary Figure 1).
However, this drug did not show any cell cycle arrest in HSAEC and HPF cells (Figure 3A and Supplementary Figure 1). Furthermore, SAHA increased sub-G1 cells and triggered apoptosis in lung cancer cells at 24 hours (Figure 3B, 3C and Supplementary Figure 2A). In HSAEC, HPF and HBEC cells, SAHA did not increase sub-G1 cells and annexin V-FITC positive cells (Figure 3B, 3C and Supplementary Figure 2A).

\section{Effects of SAHA on mitochondrial membrane potential, apoptosis-related protein levels and caspase activation in normal lung and cancer cells}

SAHA increased MMP $\left(\Delta \Psi_{\mathrm{m}}\right)$ loss in A549, Calu-6 (Figure 4A and 4B), HCC-33 and NCI-H69 cells (Supplementary Figure 2B). While SAHA slightly increased the loss of MMP $\left(\Delta \Psi_{\mathrm{m}}\right)$ in HCC-95 and HCC1588 cells, this agent did not affect $\operatorname{MMP}\left(\Delta \Psi_{\mathrm{m}}\right)$ in $\operatorname{HSAEC}$,
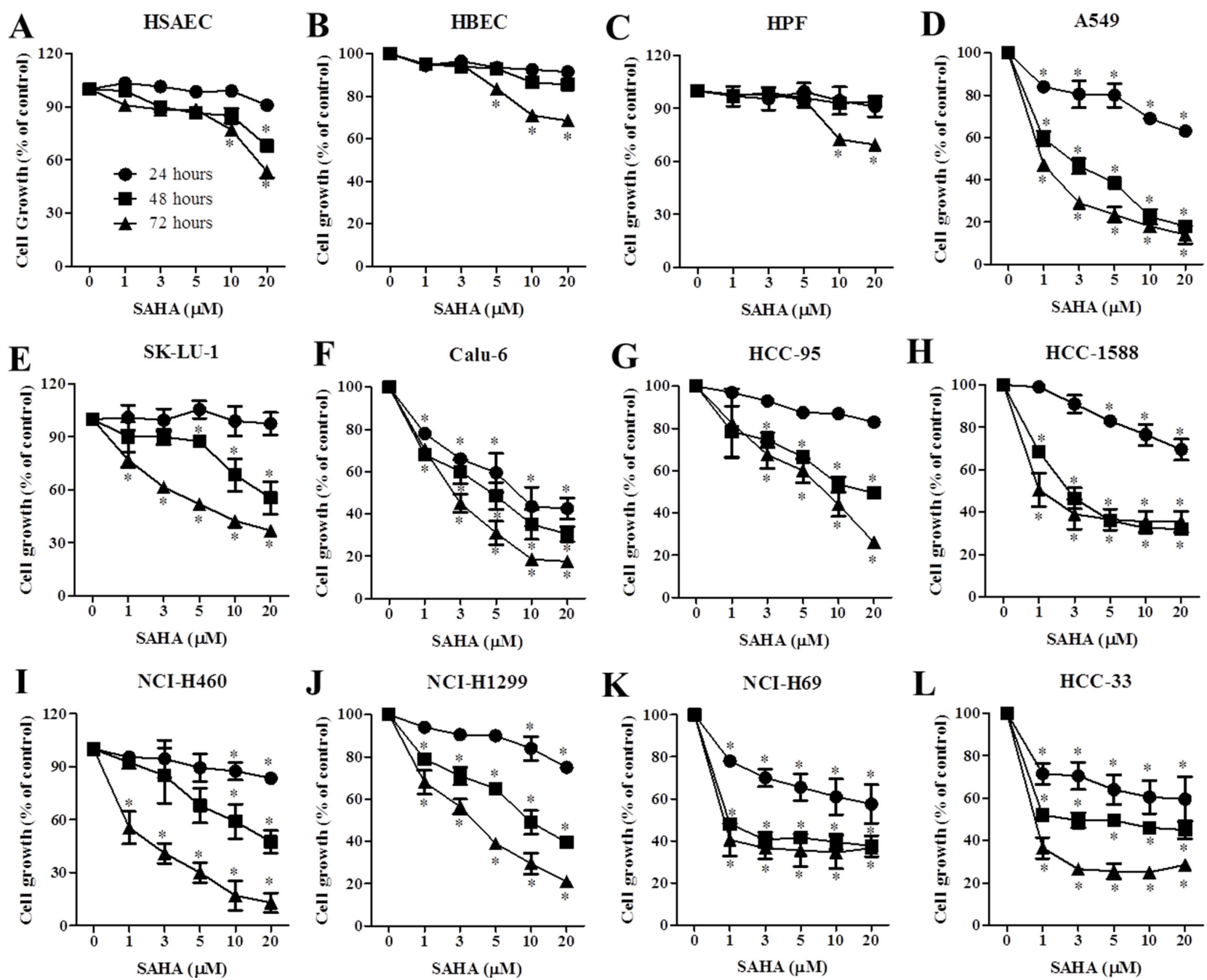

Figure 2: Effects of SAHA on cell growth in normal lung and cancer cells. Exponentially growing cells were treated with indicated concentrations of SAHA for 24, 48 and 72 hours. Graphs show cell growth in HSAEC (A), HBEC (B), HPF (C), A549 (D), SK-LU-1 (E), Calu-6 (F), HCC-95 (G), HCC-1588 (H), NCI-H460 (I), NCI-H1299 (J), NCI-H69 (K) and HCC-33 (L). * $p<0.05$ compared with SAHA-untreated control group. 
HPF, HBEC, SK-LU-1, NCI-H460 and NCI-H1299 cells (Figure 4B and Supplementary Figure 2B). In regard to apoptosis-related protein levels, the intact of poly (ADPribose) polymerase (PARP) was decreased and the cleavage for of PARP was induced by SAHA in lung cancer cells (Figure 4C and Supplementary Figure 2C). In addition, the levels of Bax were increased in SAHA-treated A549 and Calu- 6 cells whereas the levels of Bcl-2 were decreased in A549, Calu-6, HCC-33 and NCI-H69 cells (Figure 4C and Supplementary Figure 2C). SAHA did not alter the levels of PARP, Bax and Bcl-2 in HSAEC (Figure 4C).

To determine which caspase was involved in SAHA-induced apoptosis, A549 and Calu-6 cells were pre-treated each caspase inhibitor, Z-VAD (pan-caspase inhibitor), Z-DEVD (caspase-3 inhibitor), Z-IETD (caspse-8 inhibitor) and Z-LEHD (caspase-9 inhibitor) for 1 hour prior to $5 \mu \mathrm{M}$ SAHA treatment. We observed that SAHA increased caspase-3 activities in A549 and Calu-6 cells at 24 hours (Figure 4D). Moreover, all tested caspase inhibitors blocked apoptotic cell death caused by SAHA in A549 and Calu-6 cells (Figure 5A).

\section{Effects of TNF-family cytokines on apoptosis in SAHA-treated lung cancer cells}

Next, to evaluate the synergistic anti-cancer effect of TNF family cytokines in lung cancer cells, we treated with
$10 \mathrm{ng} / \mathrm{ml}$ TNF- $\alpha, 10 \mathrm{ng} / \mathrm{ml}$ TRAIL and $10 \mathrm{ng} / \mathrm{ml}$ FasL in HCC-95 and NCI-H460 cells. Treatment with $5 \mu \mathrm{M}$ SAHA did not inhibit cell growth in HPF, HCC-95 and NCI-H460 cells (Figure 5B). Although all TNF-family cytokines did not alter cell growth in SAHA-treated HPF cells, only TNF- $\alpha$ reduced the growth of SAHA-treated HCC-95 and NCI-H460 cells (Figure 5B). In addition, TNF- $\alpha$ and SAHA increased apoptotic cell death and LDH release in these cells (Figure 5C and 5D). TNF- $\alpha$ also enhanced apoptosis in SAHA-treated A549, SK-LU-1 and Calu-6 cells (Supplementary Figure 3A). Z-IETD, a caspase- 8 inhibitor, and Z-LEHD, a caspase-9 inhibitor, blocked apoptosis and necrosis caused by TNF- $\alpha$ in SAHA-treated HCC-95 and NCI-H460 cells (Figure 5C and 5D). However, necrosis inhibitors, NecroX-2 and Necrostatin-1 did not recover apoptosis and necrosis in TNF- $\alpha$ and SAHA-treated NCI-H460 cells (Supplementary Figure 3B and 3C).

\section{Effects of SAHA on TNFR1 expression level in lung cancer cells}

TNF- $\alpha$ regulates apoptosis, inflammation and survival through TNFR1 and TNFR2. Because TNF- $\alpha$ dramatically enhanced apoptotic cell death in SAHA-treated HCC-95 and NCI-H460 cells, it could be hypothesized that the level of TNFR1 or TNFR2 were increased by SAHA in these cells. As shown in Figure 6A and 6B, the expression
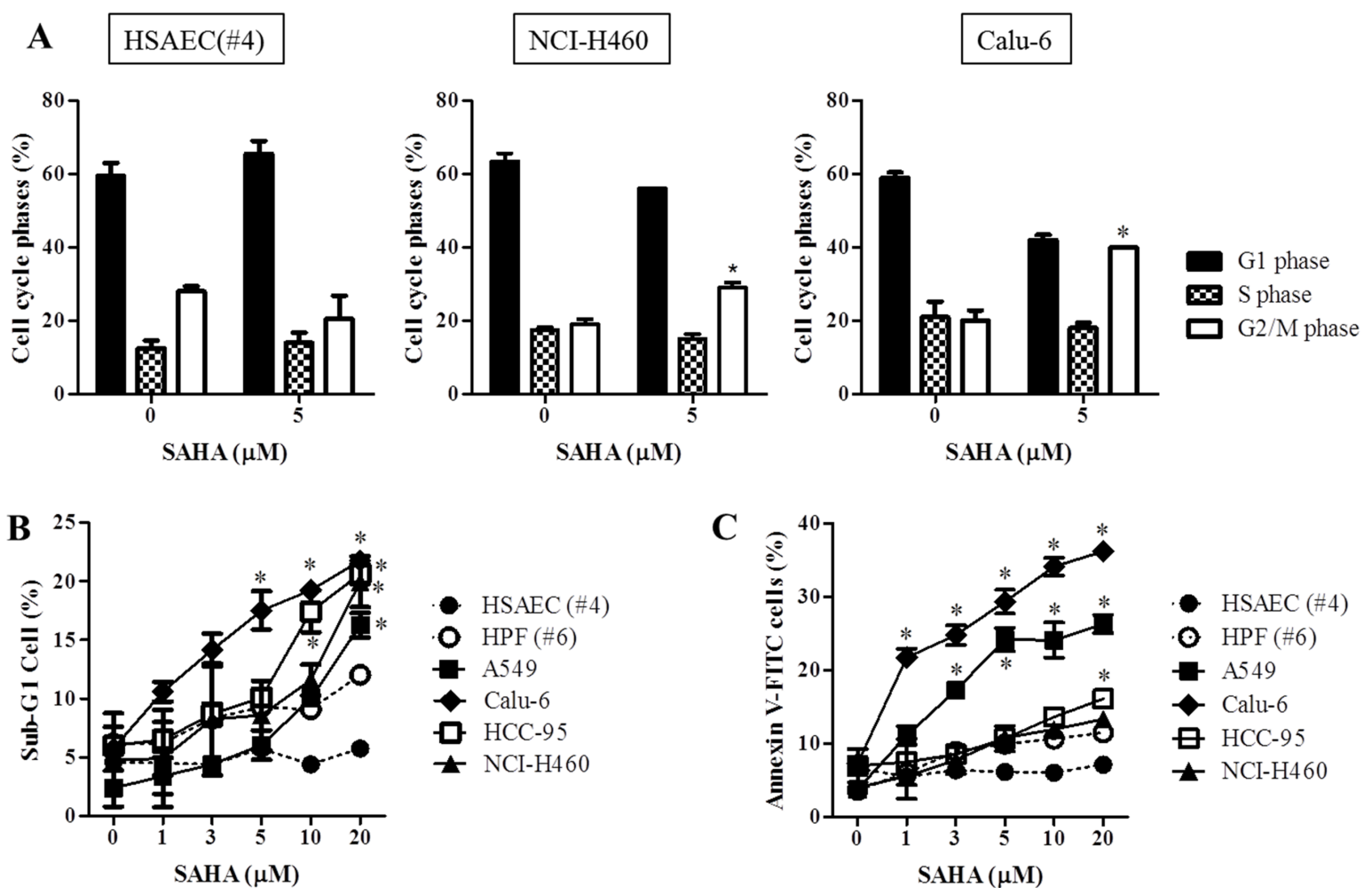

Figure 3: Effects of SAHA on cell cycle and cell death in normal lung and cancer cells. Exponentially growing cells were treated with indicated concentrations of SAHA for 24 hours. (A) Graphs show the cell cycle distributions in HSAEC (\#4), NCI-H460 and Calu-6 cells. (B) and (C) Graphs show the percent of sub-G1 (B) and annexin V-FITC positive cells (C). * $p<0.05$ compared with SAHAuntreated control group. 
levels of TNFR1 were increased in SAHA-treated HCC-95 and NCI-H460 cells. However, SAHA did not change the protein levels of TNFR2 in these cells (Figure 6B). SAHA also increased the TNFR1 expression level in A549 cells (Supplementary Figure 4A and 4B). Furthermore, acetylation of the region of TNFR1 promoter -223/-29 was increased in SAHA-treated NCI-H460 cells (Figure 6C). To determine whether TNFR1 level really affect apoptosis in NCI-H460 cells, these cells were transfected with TNFR1 siRNA. Administration of TNFR1 siRNA decreased apoptotic cell death induced by TNF- $\alpha$ and SAHA in NCI-H460 cells (Figure 6D). Similarly, TNFR1 siRNA recovered apoptosis in TNF- $\alpha$ and SAHA-treated A549 and SK-LU-1 cells (Supplementary Figure 4C).

\section{DISCUSSION}

Previous studies have been demonstrated that HDAC activity is increased in many human cancers and its inhibition would be a promising therapeutic target for cancer treatment [23-25]. In fact, overexpression of HDAC2 is observed in lung cancer tissues [26]. In this study, we observed that HDAC activity of lung cancer tissues was higher than that of normal lung tissues. Likewise, lung cancer cells showed high HDAC activity rather than normal lung cells. This data implies that HDAC inhibitor can be an effective anti-cancer drug for lung cancer. In fact, there is no difference on HDAC activities between NSCLC and SCLC cells. Even though A549 and Calu- 6 cells are the same adenocarcinoma cell line, the HDAC activities of these cells were different. This result indicates that HDAC activities are different depending on lung cancer cell types. SAHA as a HDAC inhibitor decreased the HDAC activity of nucleus in Calu-6 and NCI-H69 cells. However, it increased HDAC activities of nucleus and cytoplasm in some lung cancer cells. These results suggest that SAHA differently affects in normal lung and cancer cells due to different functional
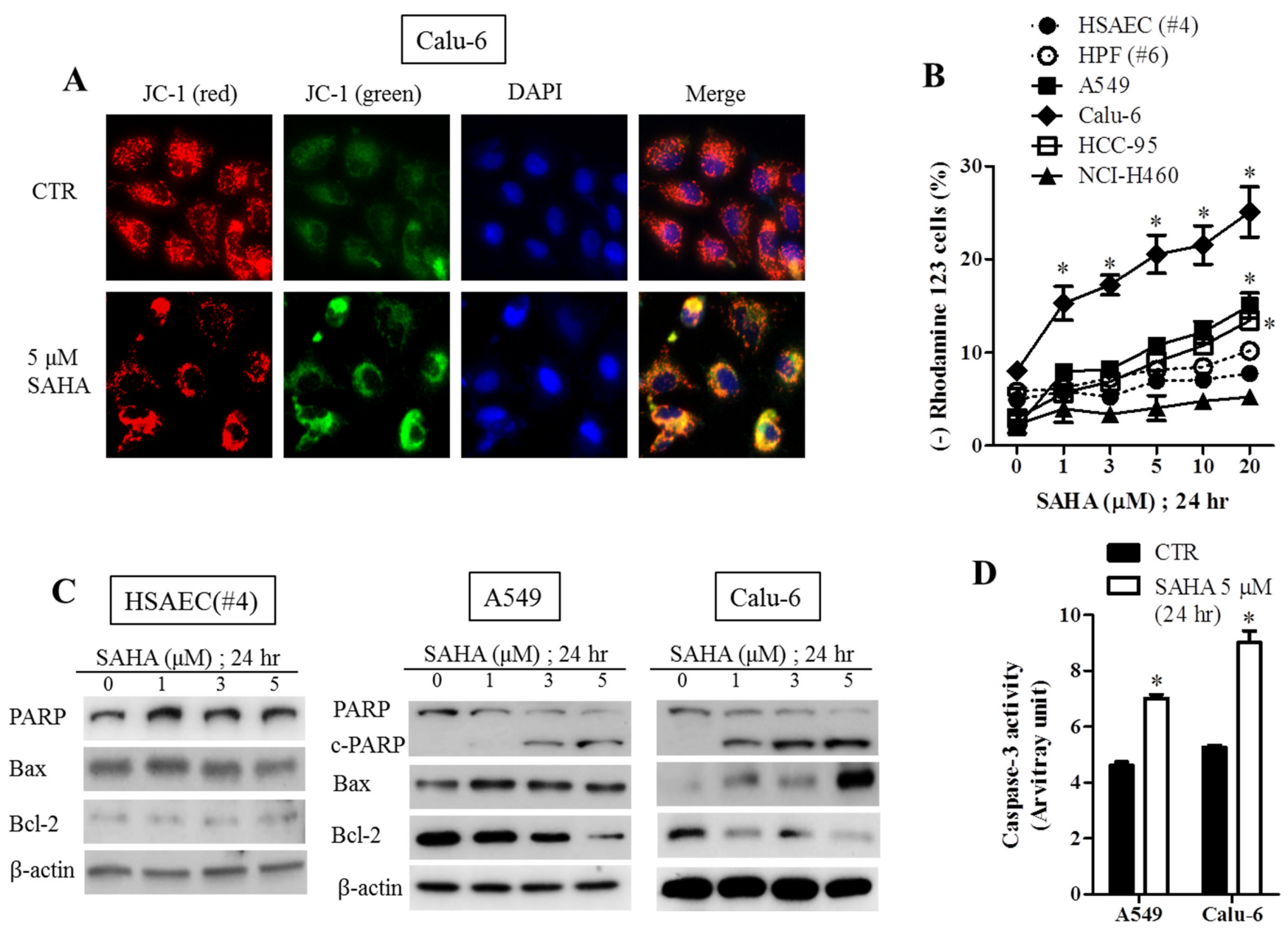

Figure 4: Effects of SAHA on mitochondrial membrane potential, apoptosis-related protein levels and caspase-3 activities in normal lung and cancer cells. Exponentially growing cells were treated with indicated concentrations of SAHA for 24 hours. (A) Representative images of JC-1 red, JC-1 green, DAPI (blue) and merge in SAHA-treated Calu-6 cells. Red fluorescent images indicate high MMP $(\Delta \Psi \mathrm{m})$. Green fluorescent images shows low $\Delta \Psi \mathrm{m}$. (B) Graph shows the rhodamine 123 negative ( $\Delta \Psi \mathrm{m}$ loss) cells. (C) The protein levels of PARP-1, c-PARP-1, Bax, Bcl-2 and $\beta$-actin in HSAEC (\#4), A549 and Calu-6 cells. (D) Graph shows the caspase-3 activities in A549 and Calu- 6 cells. ${ }^{*} p<0.05$ compared with SAHA-untreated control group. 
bioavailability in drug metabolism [27] and other HDAC might be activated as a compensatory mechanism.

As expected, SAHA inhibited the growth of lung cancer cells. We also found that SAHA decreased tumor size in lung cancer xenograft model (Supplementary Figure 5). Our results support that HDAC inhibitor show anti-cancer effect on various cancer cells including colorectal and lung [28, 29]. The susceptibility of lung cancer cells to SAHA was higher than that of normal lung cells. Some NSCLC cells showed resistance to SAHA at 24 hours. However, these cell growths were completely inhibited at 48 and 72 hours. It seems that there are no significant association between HDAC activity and SAHA resistance in lung cancer cells. These results imply that SAHA can inhibit cell growth without the inhibitory effect on HDAC. SAHA induced a G2/M phase arrest in lung cancer cells. This result supports that HDAC inhibitors triggered to a $\mathrm{G} 2 / \mathrm{M}$ phase arrest in many cancer cells such as ovarian and pancreatic cancer $[30,31]$. SAHA also increased the sub-G1 cells, annexin V-FITC positive cells and MMP $\left(\Delta \Psi_{\mathrm{m}}\right)$ loss cells at 24 hours in lung cancer cells. In addition, this agent increased cleavage of PARP, Bax and cacspase- 3 activity whereas it decreased Bcl-2 in lung cancer cells.

Apoptosis occurs through two pathways, mitochondria-mediated intrinsic pathway and death receptor-mediated extrinsic pathway [32]. It has been reported that HDAC inhibitors induce both intrinsic pathway and extrinsic pathway in cancer cells such as leukemia [33-35]. Similarly, SAHA led to apoptosis mediated by intrinsic pathway and extrinsic pathway because all caspase inhibitors prevented A549 and Calu-6 cell death.

TNF-family contains 19 ligands and 29 receptors in human [36]. TNF family ligands and receptors play an important role in numerous biological processes including apoptosis and inflammation [36]. There are three main cytokines, TNF- $\alpha$, TRAIL and FasL. When TNF- $\alpha$ binds to TNFR1, it induces caspase- 8 activation and then finally causes apoptosis [17]. TNF- $\alpha$ also activates NF- $\kappa B$
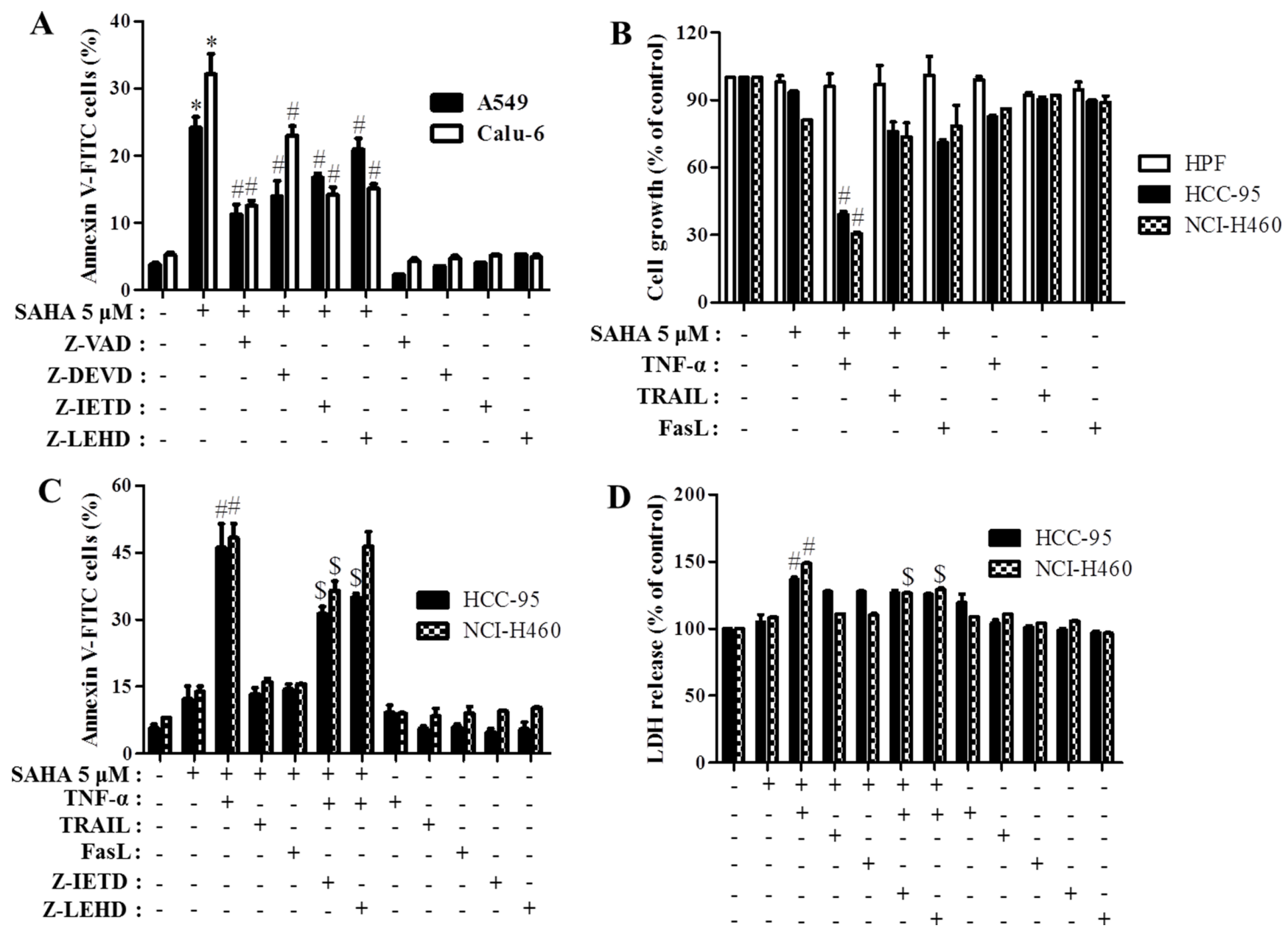

Figure 5: Effects of caspase inhibitors and TNF-family cytokines on cell growth and cell death in SAHA-treated normal lung and cancer cells. Exponentially growing cells were treated with $5 \mu \mathrm{M}$ SAHA and $15 \mu \mathrm{M}$ each caspase inhibitor, $10 \mathrm{ng} / \mathrm{ml}$ TNF- $\alpha, 10 \mathrm{ng} / \mathrm{ml} \mathrm{TRAIL}$ and $10 \mathrm{ng} / \mathrm{ml} \mathrm{FasL}$ for 24 hours. (A) and (B) Graphs show the percent of annexin V-FITC positive cells (A) and cell growth (B). (C) and (D) Graphs show the percent of annexin V-FITC positive cells (C) and LDH release compared with that in the control cells (D). ${ }^{*} p<0.05$ compared with SAHA-untreated control group. ${ }^{*} p<0.05$ compared with cells treated with SAHA only. 
pathway and AP-1 signaling for cell proliferation via binding to TNFR2 [18]. TRAIL and FasL also affect apoptosis mediated by their receptors [19]. Some reports demonstrate that HDAC inhibitor and TRAIL co-treatment sensitizes cancer cells to cell death [20, 37]. In this study, only TNF- $\alpha$ synergistically intensified cell death in SAHAtreated lung cancer cells. Especially, TNF- $\alpha$ sensitized HCC-95 and NCI-H460 cells to cell death. Co-treatment with SAHA and TNF- $\alpha$ led to not only necrosis but also apoptosis, which was induced by activations of caspase- 8 and caspase-9. Since necrosis inhibitors, NecroX-2 and Necrostatin-1 did not alter cell death, it seemed that apoptosis is major mechanism for the suppression of cell growth in TNF- $\alpha$ and SAHA-treated lung cancer cells.

HDAC inhibitor can affect the level of TNF-family receptors. It has been reported that HDAC inhibitor downregulates TNFR1 in leukemia and lung cancer cells $[38,39]$. It was also observed that SAHA decreased the level of TNFR1 in Calu-6 cells (Supplementary Figure 4A and 4B). However, our study showed that SAHA upregulated the expression level of TNFR1 in A549, HCC-95 and NCI-H460 cells. Furthermore, acetylation of the region of TNFR1 promoter -223/-29 was increased in SAHA-treated NCI-H460 cells. This data indicates that SAHA regulates the transcription of TNFR1 in NCI-H460 cells. Administration of TNFR1 siRNA recovered apoptotic cell death in TNF- $\alpha$ and SAHA-treated lung cancer cells. This result suggests that up-regulation of TNFR1 by SAHA enhances the sensitivity of TNF- $\alpha$ to lung cancer cells. Therefore, this result demonstrates that TNF- $\alpha$ can be a noble combination agent for HDAC inhibitor-based cancer therapy.

In conclusion, SAHA inhibited the growth of lung cancer cells via a G2/M phase arrest and caspasedependent apoptosis regardless of the inhibitory effect on HDAC. SAHA also enhanced apoptotic effect of TNF- $\alpha$ in human lung cancer cells through up-regulation of TNFR1 (Figure 7). These results suggest that TNF- $\alpha$ may be a key to improve the anti-cancer effect of HDAC inhibitors in lung cancer.
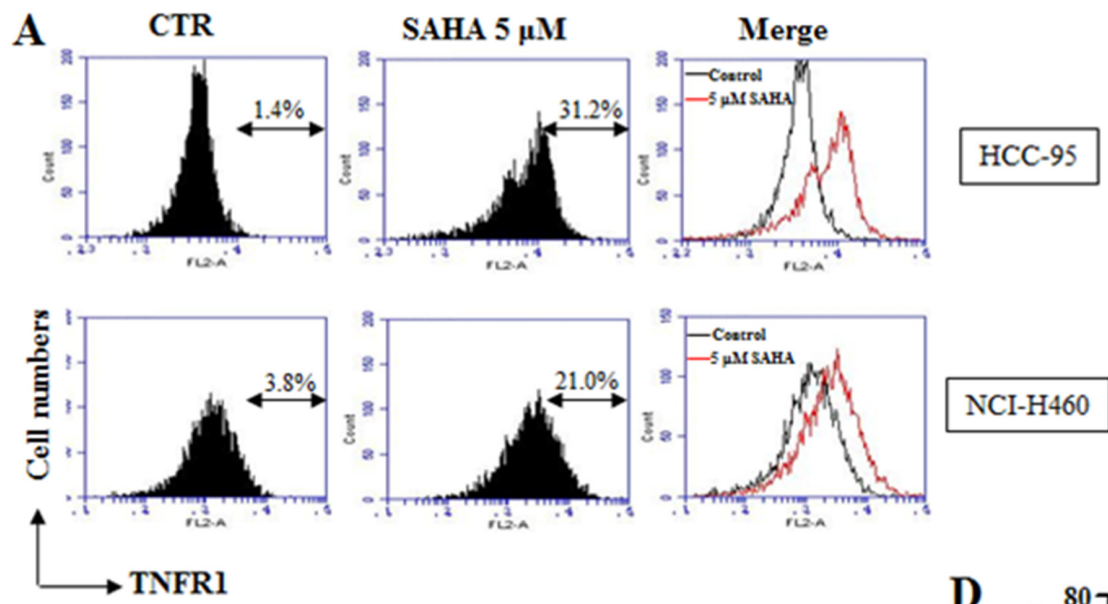

\section{NCI-H460}

B
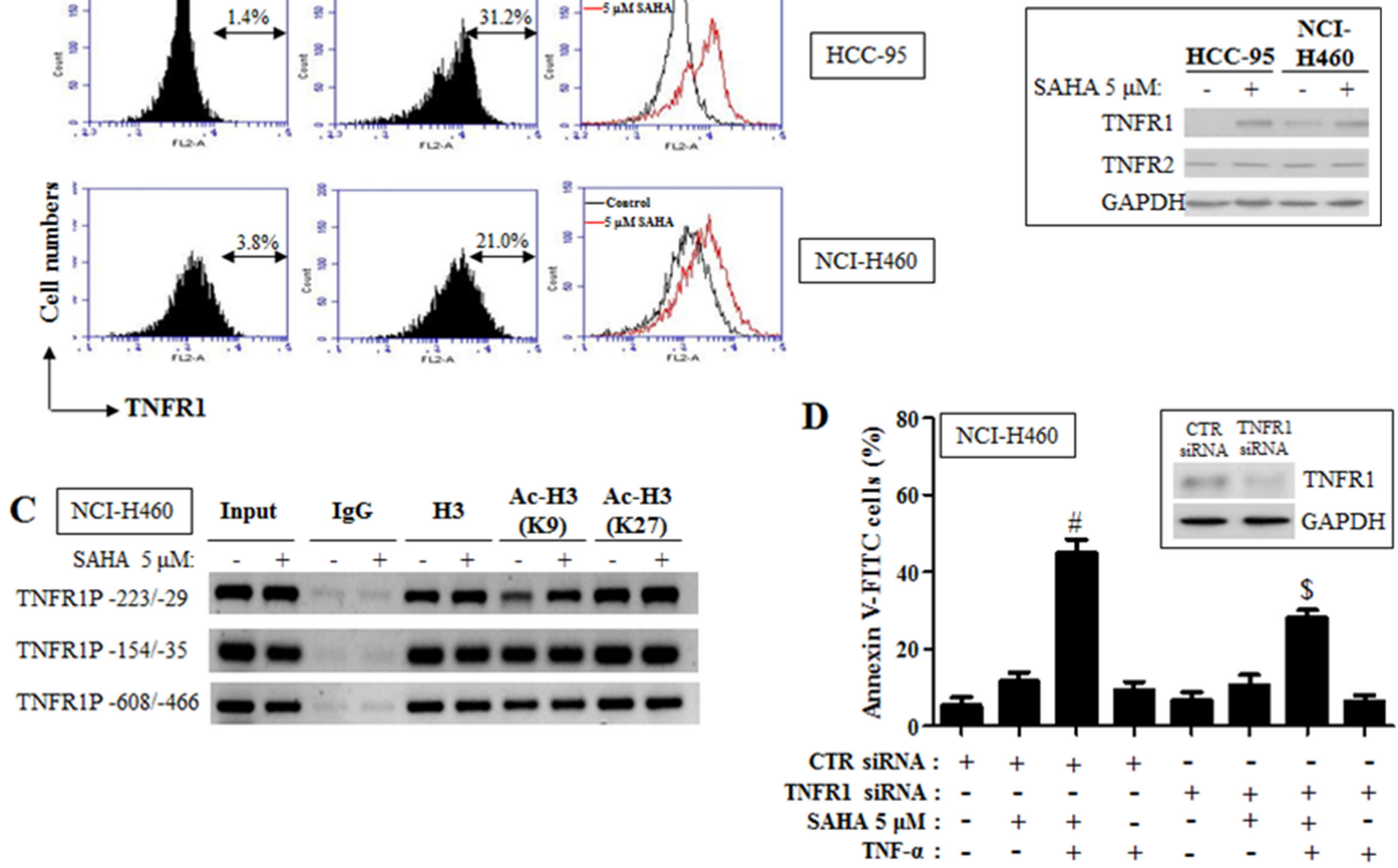

Figure 6: Effects of SAHA on TNFR1 expression in HCC-95 and NCI-H460 cells. Exponentially growing cells were treated with $5 \mu \mathrm{M}$ SAHA for 24 hours. (A) Each figure shows a representative for TNFR1 expression in HCC-95 and NCI-H460 cells. (B) The protein levels of TNFR1, TNFR2 and GAPDH in HCC-95 and NCI-H460 cells. (C) ChIP assay using H3, Ac-H3 (K9) and AC-H3 (K27) antibodies, and primers for the TNFR1 promoter regions. NCI-H460 cells were transfected with nontarget control (CTR) siRNA or TNFR1

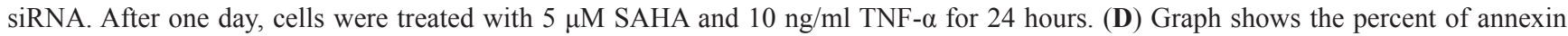
V-FITC positive cells. The inside figure indicates the protein levels of TNFR1 and GAPDH in NCI-H460 cells. ${ }^{\#} p<0.05$ compared with cells treated with SAHA only. ${ }^{s} p<0.05$ compared with cells treated with SAHA and TNF- $\alpha$. 


\section{MATERIALS AND METHODS}

\section{Cell culture}

The human lung adenocarcinoma A549, SK-LU-1, Calu-6, squamous cell carcinoma HCC-95, HCC-1588, large cell carcinoma NCI-H460, NCI-H1299, SCLC HCC-33 and NCI-H69 cells were obtained from the American Type Culture Collection (ATCC, Manassas, VA). Human small airway epithelial cells (HSAEC), human bronchial epithelial cells (HBEC), human pulmonary artery endothelial cells (HPEC) and human pulmonary fibroblast (HPF) cells were obtained from PromoCell GmbH (Heidelberg, Germany). These cells were maintained in incubator containing 5\% $\mathrm{CO}_{2}$ at $37^{\circ} \mathrm{C}$. Normal lung and cancer cells were cultured RPMI-1640 containing 10\% fetal bovine serum (FBS, Sigma-Aldrich Co., St. Louis, MO) and $1 \%$ penicillinstreptomycin (Gibco BRL, Grand Island, NY). Cells were grown in $100 \mathrm{~mm}$ plastic cell culture dishes (BD Falcon. Franklin Lakes, NJ) and harvested with a trypsin-EDTA (Gibco BRL). HSAEC, HBEC, HPEC and HPF cells were used between passages four to seven.

\section{Reagents}

Protein lysates of normal lung tissue, adenocarcinoma tissues, squamous cell carcinoma tissues and large cell carcinoma tissues were purchased from OriGene Technology (Rockville, MD) (Supplementary Table 1). SAHA from Cayman Chemical Company (Ann Arbor, MI) was dissolved in dimethyl sulfoxide (DMSO; Sigma-
Aldrich Co.) at $10 \mathrm{mM}$ as a stock solution. The pan-caspase inhibitor (Z-VAD-FMK; benzyloxycarbonyl-Val-Ala-Aspfluoromethylketone), caspase-3 inhibitor (Z-DEVD-FMK; benzyloxycarbonyl-Asp-Glu-Val-Asp-fluoromethylketone), caspase-8 inhibitor (Z-IETD-FMK; benzyloxycarbonyl-IleGlu-Thr-Asp-fluoromethylketone) and caspase-9 inhibitor (Z-LEHD-FMK; benzyloxycarbonyl-Leu-Glu-His-Aspfluoromethylketone) were obtained from R\&D Systems, Inc. (Minneapolis, $\mathrm{MN}$ ) and were dissolved in DMSO at $10 \mathrm{mM}$ to serve as stock solutions. TNF- $\alpha$, TRAIL and FasL were also obtained from $R \& D$ systems, Inc. and were dissolved in water at $10 \mathrm{mg} / \mathrm{ml}$ as a stock solution. NecroX-2 and Necrostatin-1 from Enzo Life Sciences (Plymouth Meeting, PA) were dissolved in DMSO at $1 \mathrm{mM}$ and $50 \mathrm{mM}$ as a stock solution, respectively. Cells were pretreated with each caspase inhibitor for 1 hour prior to SAHA treatment. DMSO (0.01\%) was used as a controlvehicle and it did not affect cell growth and death.

\section{Measurement of HDAC activity}

The HDAC activity was measured by using the HDAC assay kit, according to manufacturer's instructions (Millipore, Billerica, MA). Briefly, $1 \times 10^{6}$ cells in $60 \mathrm{~mm}$ culture dish (BD Falcon) were incubated with or without $5 \mu \mathrm{M}$ SAHA for 24 hours. Then cells were washed with PBS and added in 4 volumes of lysis buffer (R\&D systems, Inc.). Thirty $\mu \mathrm{g}$ of total protein were used to measure the HDAC activity. These were added to each well in 96-well microtiter plates (SPL Life Sciences, Pocheon, Gyeonggido, Korea) with HDAC substrate provided from the

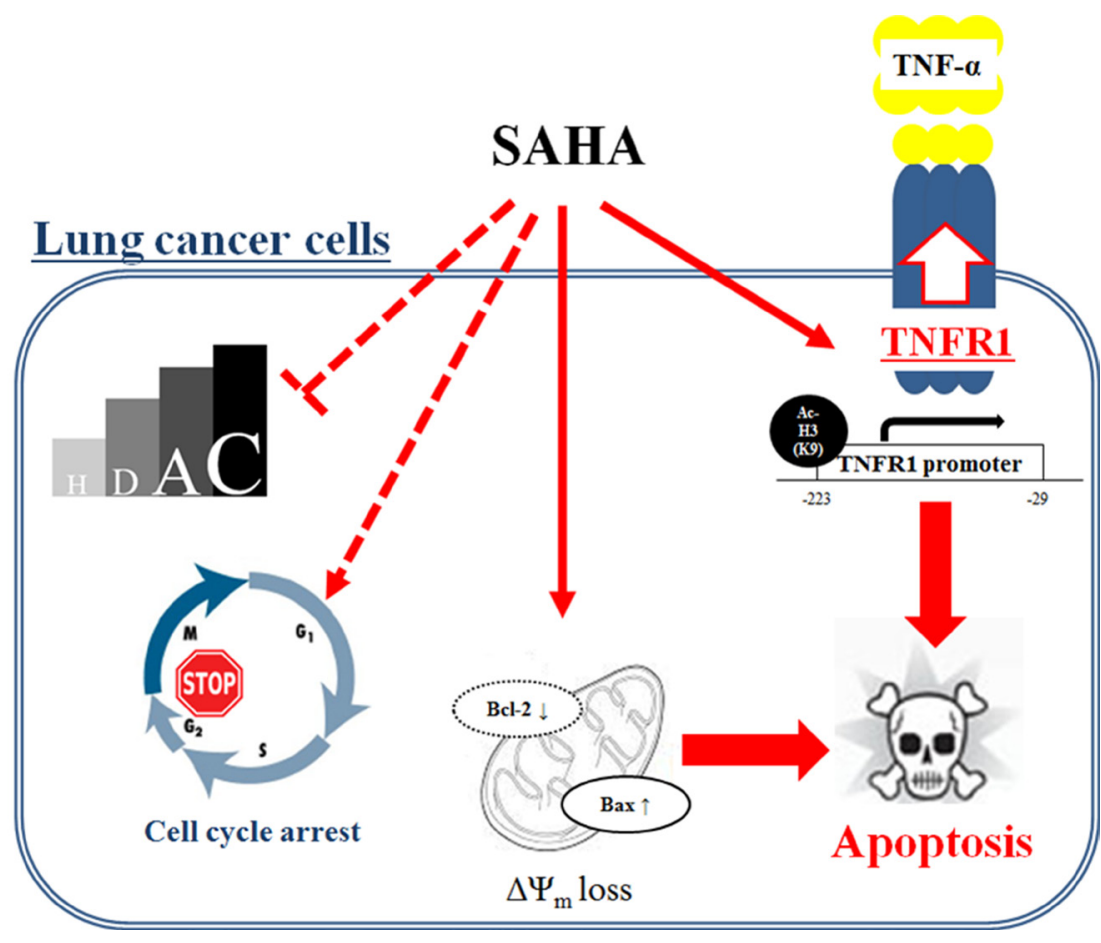

Figure 7: Schematic diagram of SAHA-induced cell death in lung cancer cells. 
kit at $37^{\circ} \mathrm{C}$ for 1 hour. The optical density of each well was measured at $405 \mathrm{~nm}$ by using a microplate reader (Synergy $^{\mathrm{TM}}$ 2, BioTekR Instruments Inc., Winooski, VT).

\section{Cell growth inhibition assay}

The effect of SAHA on growth inhibition in normal lung and cancer cells was determined by the 3-(4,5-dimethylthiazol-2-yl)-2,5-diphenyltetrazolium bromide (MTT, Sigma-Aldrich Co.) assay. Briefly, $5 \times 10^{3}$ cells in 96-well microtiter plate (SPL Life Sciences) were incubated with the indicated concentrations of SAHA with or without TNF- $\alpha$, TRAIL or FasL for indicated times. Then twenty microliter of MTT solution $[2 \mathrm{mg} / \mathrm{mL}$ in phosphate-buffered saline (PBS)] was added to each well in 96-well plates. The plates were incubated for 4 hours at $37^{\circ} \mathrm{C}$. Medium in plates was removed by pipetting, and $200 \mu 1$ DMSO was added to each well to solubilize the formazan crystals. The optical density was measured at $570 \mathrm{~nm}$ using a microplate reader $\left(\right.$ Synergy $^{\mathrm{TM}}$ 2, BioTekR Instruments Inc.).

\section{Cell cycle and sub-G1 analysis}

Cell cycle and sub-G1 analysis were determined by propidium iodide (PI, Sigma-Aldrich Co.; $\mathrm{Ex} / \mathrm{Em}=488 \mathrm{~nm} / 617 \mathrm{~nm}$ ) staining. Briefly, $1 \times 10^{6}$ cells in $60 \mathrm{~mm}$ culture dish (BD Falcon) were incubated with the indicated concentrations of SAHA for 24 hours. Cells were washed with PBS and then incubated with $10 \mu \mathrm{g} / \mathrm{ml}$ PI with RNase at $37^{\circ} \mathrm{C}$ for $30 \mathrm{~min}$. Cell cycle distribution and sub-G1 DNA content cells were measured and analyzed with an Accuri C6 flow cytometer (BD Sciences, Franklin Lakes, NJ).

\section{Detection of apoptosis}

Apoptosis was detected by staining cells with annexin V-fluorescein isothiocyanate (FITC, Life Technologies, Carlsbad, CA ; Ex/Em $=488 \mathrm{~nm} / 519 \mathrm{~nm})$. Briefly, $1 \times 10^{6}$ cells in $60 \mathrm{~mm}$ culture dish (BD Falcon) were incubated with the indicated concentrations of SAHA with or without each caspase inhibitor, TNF- $\alpha$, TRAIL or FasL for 24 hours. Then cells were washed twice with cold PBS and added $500 \mu \mathrm{l}$ of binding buffer $(10 \mathrm{mM}$ HEPES/NaOH pH 7.4, $140 \mathrm{mM} \mathrm{NaCl}, 2.5 \mathrm{mM} \mathrm{CaCl}{ }_{2}$ ) at a concentration of $1 \times 10^{6} \mathrm{cells} / \mathrm{ml}$. Five microliters of annexin V-FITC and PI were added to these cells, which were analyzed with an Accuri C6 flow cytometer (BD Sciences).

\section{Measurement of MMP $(\Delta \Psi \mathrm{m})$}

$\operatorname{MMP}(\Delta \Psi \mathrm{m})$ levels were measured using rhodamine 123 (Sigma-Aldrich Co.; Ex/Em = $485 \mathrm{~nm} / 535 \mathrm{~nm}$ ) and JC-1 dyes (Enzo Life Sciences ; Ex/Em $=515 \mathrm{~nm} / 529 \mathrm{~nm}$ ). Briefly, $5 \times 10^{4}$ cells in 12 well culture plate (BD Falcon) were incubated with the indicated concentration of SAHA for 24 hours. Cells were washed twice with PBS and incubated with $0.1 \mu \mathrm{g} / \mathrm{ml}$ rhodamine 123 or $10 \mu \mathrm{g} / \mathrm{ml}$ $\mathrm{JC}-1$ at $37^{\circ} \mathrm{C}$ for $30 \mathrm{~min}$. For staining nucleus, cells were

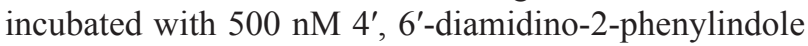
(DAPI, Life Technologies, Ex/Em $=358 \mathrm{~nm} / 461 \mathrm{~nm}$ ) at $37^{\circ} \mathrm{C}$ for $30 \mathrm{~min}$. The intensity of rhodamine 123 staining was determined by Accuri C6 flow cytometry (BD Sciences). The negative staining of rhodamine 123 from cells indicated the loss of MMP $(\Delta \Psi \mathrm{m})$ in cells. After incubation with JC-1 and DAPI, cells were washed three times with PBS and images were collected by using a fluorescence microscope (FLoid ${ }^{\circledR}$ Cell Imaging Station, Life Technologies) in $\times 400$ magnification. Green fluorescence indicates a monomer at low $\Delta \Psi \mathrm{m}$ and red fluorescence presents high $\Delta \Psi \mathrm{m}$.

\section{Western blotting}

The protein expression levels were evaluated by Western blotting. Briefly, $1 \times 10^{6}$ cells in $60 \mathrm{~mm}$ culture dish (BD Falcon) were incubated with the indicated concentrations of SAHA for 24 hours. Then cells were washed with PBS and added in 4 volumes of lysis buffer (Intron Biotechnology, Seongnam, Gyeonggi-do, Korea). Thirty $\mu \mathrm{g}$ of total protein were resolved by $4-20 \%$ SDS-PAGE gels, and then transferred to Immobilon-P PVDF membranes (Millipore) by electroblotting. Then membranes were probed with anti-PARP, anti-cPARP, anti-Bax, anti-Bcl-2, anti-TNFR2 (Cell signaling Technology, Danvers, MA), anti-TNFR1, anti- $\beta$-actin and anti-GAPDH (Santa Cruz Biotechnology, Santa Cruz, CA). Membranes were incubated with horseradish peroxidase-conjugated secondary antibodies. Blots were developed using an EZ-Western Lumi Pico ECL solution kit (DoGen, Seoul, Korea).

\section{Measurement of caspase-3 activity}

The caspase- 3 activity was assessed by using the caspase- 3 colorimetric assay kit (R\&D systems, Inc.) Briefly, $1 \times 10^{6}$ cells in $60 \mathrm{~mm}$ culture dish (BD Falcon) were incubated with $5 \mu \mathrm{M}$ SAHA for 24 hours. Then cells were washed with PBS and added in 4 volumes of lysis buffer (R\&D systems, Inc.). Fifty $\mu \mathrm{g}$ of total protein were used to measure the caspase-3 activity. These were added to each well in 96-well microtiter plates (SPL Life Sciences) with DEVD-pNA as a caspase-3 substrate. The plates were incubated for 1 hour at $37^{\circ} \mathrm{C}$. The optical density of each well was measured at $405 \mathrm{~nm}$ by using a microplate reader $\left(\right.$ Synergy $^{\mathrm{TM}}$ 2).

\section{Lactate dehydrogenase (LDH) release assay}

Necrosis in cells treated with SAHA and/or TNF family cytokines was evaluated by LDH kit (Sigma-Aldrich Co.) Briefly, $1 \times 10^{6}$ cells in $60 \mathrm{~mm}$ culture dish (BD Falcon) 
were incubated with the indicated concentrations of SAHA with or without TNF family cytokines for 24 hours. After treatment, the cell culture media were collected and centrifuged for $5 \mathrm{~min}$ at $1500 \mathrm{rpm}$. Fifty $\mu \mathrm{l}$ of the media supernatant was added to a 96 well plate along with $\mathrm{LDH}$ assay reagent and then incubated at room temperature for $30 \mathrm{~min}$. The absorbance values were measured at $490 \mathrm{~nm}$ using a microplate reader $\left(\right.$ Synergy $\left.^{\mathrm{TM}} 2\right)$. LDH release was expressed as the percentage of extracellular LDH activity compared with the control cells.

\section{Measurement of TNFR1 expression by using flow cytometer}

Surface expression of TNFR1 was detected by PE conjugated TNFR1 antibody (Santa Cruz Biotechnology). PE conjugated Armenian hamster IgG (Santa Cruz Biotechnology) was used as an isotype control. Briefly, $5 \times 10^{4}$ cells in 12 well culture plate (BD Falcon) were incubated with the indicated $5 \mu \mathrm{M}$ SAHA for 24 hours. Then cells were washed twice with cold PBS and added $500 \mu \mathrm{l}$ of PBS at a concentration of $1 \times 10^{6}$ cells $/ \mathrm{ml}$. Ten microliters of PE conjugated TNFR1 antibodies or five microliters of PE conjugated Armentian hamster IgG were added to these cells, which were analyzed with an Accuri C6 flow cytometer (BD Sciences).

\section{Chromatin immunoprecipitation (ChIP) assay}

ChIP assay was performed using SimpleChIP Enzymatic Chromatin IP Kit (\#9003 Cell signaling Technology) according to manufacturer's instructions. Briefly, $1 \times 10^{6}$ cells in $60 \mathrm{~mm}$ culture dish (BD Falcon) were incubated with $5 \mu \mathrm{M}$ SAHA for 24 hours. Cells are fixed with $1 \%$ formaldehyde to cross-link and then DNA is digested with Micrococcal Nuclease for $20 \mathrm{~min}$ at $37^{\circ} \mathrm{C}$. The digested DNA incubated overnight at $4^{\circ} \mathrm{C}$ with 1 $\mu \mathrm{g}$ of following antibody: rabbit IgG, anti-H3 (1b2b2), anti-AcH3(K9) and anti-AcH3 (K27) (Cell signaling Technology). Immunoprecipitated samples were eluted using protein $\mathrm{G}$ magnetic beads, crosslinks reversed and then DNA purified according to manufacturer's instruction. PCR was performed using specific primers for the regions of the TNFR1 promoter, TNFR1-223 to -29 (forward 5'- GAT TGGTGGGTTGGGGGCACA and reverse 5'- ATT AAAGCAGAGAGGAGGGGAGAGA), TNFR1-154 to -35 (forward 5'- AGTTAAAGAACGTTGGGCCTCCT and reverse 5'- GCAGAGAGGAGGGGAGAGAAGG) and TNFR1-608 to -466 (forward 5'- TTCCCAAGAAA GAGGGAGACTAGGA and reverse 5'- CTGGGGTTC CTGTAAGGATTTGTTC). PCR products were run on $2 \%$ agarose gel.

\section{Transfection of cells with TNFR1 siRNA}

Gene silencing of TNFR1 was performed by using siRNA. A nonspecific control (CTR) siRNA duplex [5'-CC
UACGCCACCAAUUUCGU(dTdT)-3'] and TNFR1 siRNA duplex [5'-CCUGGACAAGCACAUAGCA(dT dT)-3'] were purchased from the Bioneer Corp. (Daejeon, South Korea). In brief, $2.5 \times 10^{5}$ cells in six-well plates (Nunc) were incubated in RPMI-1640 supplemented with $10 \%$ FBS. The next day, cells (approximately 30-40\% confluence) in each well were transfected with the CTR or TNFR1 siRNA duplex [80 pmol in Opti-MEM (GIBCO BRL)] using LipofectAMINE 2000 (Invitrogen, Brandford, CT). One day later, cells were treated with or without $5 \mu \mathrm{M}$ SAHA and $10 \mathrm{ng} / \mathrm{ml} \mathrm{TNF}-\alpha$ for additional 24 hours. The transfected cells were used for Western blot analysis and annexin V-FITC staining measurements.

\section{Statistical analysis}

The results represent the mean of at least three independent experiments (mean \pm SD). The data were analyzed using Instat software (GraphPad Prism5, San Diego, CA). The Student's $t$-test or one-way analysis of variance (ANOVA) with post hoc analysis using Tukey's multiple comparison test was used for parametric data. Statistical significance was defined as $p<0.05$.

\section{Abbreviations}

SAHA, suberoylanilide hydroxamic acid; HDAC, histone deacetylase; TNF, tumor necrosis factor; TRAIL, TNF-related apoptosis-inducing ligand; FasL, Fas ligand; TNFR, TNF receptor; NSCLC, non-small cell lung cancer; SCLC, small cell lung cancer; HSAEC, human small airway epithelial cells; HBEC, human bronchial epithelial cells; HPEC, human pulmonary artery endothelial cells; HPF, human pulmonary fibroblast; FBS, fetal bovine serum; MTT, 3-(4,5-dimethylthiazol-2-yl) -2,5-diphenyltetrazolium bromide; PI, propidium iodide; FITC, fluorescein isothiocyanate; Z-VAD-FMK, benzyloxycarbonyl-Val-Ala-Asp-fluoromethylketone; ZDEVD-FMK, benzyloxycarbonyl-Asp-Glu-Val-Aspfluoromethylketone; Z-IETD-FMK, benzyloxycarbonylIle-Glu-Thr-Asp-fluoromethylketone; Z-LEHD-FMK, benzyloxycarbonyl-Leu-Glu-His-Asp-fluoromethylketone; MMP $(\Delta \Psi \mathrm{m})$, mitochondrial membrane potential; DAPI, 4', 6'-diamidino-2-phenylindole; LDH, lactate dehydrogenase; ChIP, chromatin immunoprecipitation

\section{ACKNOWLEDGMENTS AND FUNDING}

This study was supported by a grant from the National Research Foundation of Korea (NRF) funded by the Korean government (MSIP; No. 2008-0062279 and 2016R1A2B4007773).

\section{CONFLICTS OF INTEREST}

None declared. 


\section{REFERENCES}

1. Delcuve GP, Khan DH, Davie JR. Roles of histone deacetylases in epigenetic regulation: emerging paradigms from studies with inhibitors. Clin Epigenetics. 2012; 4:5. doi: 10.1186/1868-7083-4-5.

2. Sudo T, Mimori K, Nishida N, Kogo R, Iwaya T, Tanaka F, Shibata K, Fujita H, Shirouzu K, Mori M. Histone deacetylase 1 expression in gastric cancer. Oncol Rep. 2011; 26:777-82. doi: 10.3892/or.2011.1361.

3. Ververis K, Karagiannis TC. An atlas of histone deacetylase expression in breast cancer: fluorescence methodology for comparative semi-quantitative analysis. Am J Transl Res. 2012; 4:24-43.

4. Song $\mathrm{Y}$, Shiota M, Tamiya S, Kuroiwa K, Naito S, Tsuneyoshi M. The significance of strong histone deacetylase 1 expression in the progression of prostate cancer. Histopathology. 2011; 58:773-80. doi: 10.1111/j.1365-2559.2011.03797.x.

5. Lakshmaiah KC, Jacob LA, Aparna S, Lokanatha D, Saldanha SC. Epigenetic therapy of cancer with histone deacetylase inhibitors. J Cancer Res Ther. 2014; 10:469-78. doi: 10.4103/0973-1482.137937.

6. Russo D, Durante C, Bulotta S, Puppin C, Puxeddu E, Filetti S, Damante G. Targeting histone deacetylase in thyroid cancer. Expert Opin Ther Targets. 2013; 17:179-93. doi: $10.1517 / 14728222.2013 .740013$.

7. Chien W, Lee DH, Zheng Y, Wuensche P, Alvarez R, Wen DL, Aribi AM, Thean SM, Doan NB, Said JW, Koeffler HP. Growth inhibition of pancreatic cancer cells by histone deacetylase inhibitor belinostat through suppression of multiple pathways including HIF, NFkB, and $\mathrm{mTOR}$ signaling in vitro and in vivo. Mol Carcinog. 2014; 53:722-35. doi: 10.1002/mc.22024.

8. Millward M, Price T, Townsend A, Sweeney C, Spencer A, Sukumaran S, Longenecker A, Lee L, Lay A, Sharma G, Gemmill RM, Drabkin HA, Lloyd GK, et al. Phase 1 clinical trial of the novel proteasome inhibitor marizomib with the histone deacetylase inhibitor vorinostat in patients with melanoma, pancreatic and lung cancer based on in vitro assessments of the combination. Invest New Drugs. 2012; 30:2303-17. doi: 10.1007/s10637-011-9766-6.

9. Doi T, Hamaguchi T, Shirao K, Chin K, Hatake K, Noguchi K, Otsuki T, Mehta A, Ohtsu A. Evaluation of safety, pharmacokinetics, and efficacy of vorinostat, a histone deacetylase inhibitor, in the treatment of gastrointestinal (GI) cancer in a phase I clinical trial. Int J Clin Oncol. 2013; 18:87-95. doi: 10.1007/s10147-011-0348-6.

10. Kirschbaum M, Gojo I, Goldberg SL, Bredeson C, Kujawski LA, Yang A, Marks P, Frankel P, Sun X, Tosolini A, Eid JE, Lubiniecki GM, Issa JP. A phase 1 clinical trial of vorinostat in combination with decitabine in patients with acute myeloid leukaemia or myelodysplastic syndrome. Br J Haematol. 2014; 167:185-93. doi: 10.1111/ bjh.13016.
11. Chiao MT, Cheng WY, Yang YC, Shen CC, Ko JL. Suberoylanilide hydroxamic acid (SAHA) causes tumor growth slowdown and triggers autophagy in glioblastoma stem cells. Autophagy. 2013; 9:1509-26. doi: 10.4161/ auto. 25664 .

12. Chiu HW, Yeh YL, Wang YC, Huang WJ, Chen YA, Chiou YS, Ho SY, Lin P, Wang YJ. Suberoylanilide hydroxamic acid, an inhibitor of histone deacetylase, enhances radiosensitivity and suppresses lung metastasis in breast cancer in vitro and in vivo. PLoS One. 2013; 8:e76340. doi: 10.1371/journal.pone.0076340.

13. Bremer E. Targeting of the tumor necrosis factor receptor superfamily for cancer immunotherapy. ISRN Oncol. 2013; 2013:371854. doi: 10.1155/2013/371854.

14. Cavallini C, Lovato O, Bertolaso A, Pacelli L, Zoratti E, Zanolin E, Krampera M, Zamo A, Tecchio C, Cassatella MA, Pizzolo G, Scupoli MT. The TNF-family cytokine TL1A inhibits proliferation of human activated B cells. PLoS One. 2013; 8:e60136. doi: 10.1371/journal. pone. 0060136 .

15. Ma J, Bang BR, Lu J, Eun SY, Otsuka M, Croft M, Tobias P, Han J, Takeuchi O, Akira S, Karin M, Yagita H, Kang YJ. The TNF family member 4-1BBL sustains inflammation by interacting with TLR signaling components during latephase activation. Sci Signal. 2013; 6:ra87. doi: 10.1126/ scisignal.2004431.

16. Varfolomeev E, Goncharov T, Maecker H, Zobel K, Komuves LG, Deshayes K, Vucic D. Cellular inhibitors of apoptosis are global regulators of NF-kappaB and MAPK activation by members of the TNF family of receptors. Sci Signal. 2012; 5:ra22. doi: 10.1126/scisignal.2001878.

17. Naude PJ, den Boer JA, Luiten PG, Eisel UL. Tumor necrosis factor receptor cross-talk. FEBS J. 2011; 278:88898. doi: 10.1111/j.1742-4658.2011.08017.x.

18. Bruggeman LA, Drawz PE, Kahoud N, Lin K, Barisoni L, Nelson PJ. TNFR2 interposes the proliferative and NFkappaB-mediated inflammatory response by podocytes to TNF-alpha. Lab Invest. 2011; 91:413-25. doi: 10.1038/ labinvest.2010.199.

19. Fulda S. Histone deacetylase (HDAC) inhibitors and regulation of TRAIL-induced apoptosis. Exp Cell Res. 2012; 318:1208-12. doi: 10.1016/j.yexcr.2012.02.005.

20. Meng X, Brachova P, Yang S, Xiong Z, Zhang Y, Thiel KW, Leslie KK. Knockdown of MTDH sensitizes endometrial cancer cells to cell death induction by death receptor ligand TRAIL and HDAC inhibitor LBH589 co-treatment. PLoS One. 2011; 6:e20920. doi: 10.1371/journal.pone.0020920.

21. Langevin SM, Kratzke RA, Kelsey KT. Epigenetics of lung cancer. Transl Res. 2015; 165:74-90. doi: 10.1016/j. $\operatorname{trs} 1.2014 .03 .001$.

22. Reguart N, Rosell R, Cardenal F, Cardona AF, Isla D, Palmero R, Moran T, Rolfo C, Pallares MC, Insa A, Carcereny E, Majem M, De Castro J, et al. Phase I/ II trial of vorinostat (SAHA) and erlotinib for nonsmall cell lung cancer (NSCLC) patients with epidermal 
growth factor receptor (EGFR) mutations after erlotinib progression. Lung Cancer. 2014; 84:161-7. doi: 10.1016/j. lungcan.2014.02.011.

23. De Souza C, Chatterji BP. HDAC Inhibitors as Novel AntiCancer Therapeutics. Recent Pat Anticancer Drug Discov. 2015.

24. West AC, Johnstone RW. New and emerging HDAC inhibitors for cancer treatment. J Clin Invest. 2014; 124:30-9. doi: 10.1172/JCI69738.

25. Al-Janadi A, Chandana SR, Conley BA. Histone deacetylation : an attractive target for cancer therapy? Drugs R D. 2008; 9:369-83. doi: 10.2165/0126839-20080906000003.

26. Jung KH, Noh JH, Kim JK, Eun JW, Bae HJ, Xie HJ, Chang YG, Kim MG, Park H, Lee JY, Nam SW. HDAC2 overexpression confers oncogenic potential to human lung cancer cells by deregulating expression of apoptosis and cell cycle proteins. J Cell Biochem. 2012; 113:2167-77. doi: $10.1002 /$ jcb. 24090 .

27. Testa B, Kramer SD. The biochemistry of drug metabolism-an introduction: part 4. reactions of conjugation and their enzymes. Chem Biodivers. 2008; 5:2171-336. doi: 10.1002/ cbdv.200890199.

28. Chun SM, Lee JY, Choi J, Lee JH, Hwang JJ, Kim CS, Suh YA, Jang SJ. Epigenetic modulation with HDAC inhibitor CG200745 induces anti-proliferation in non-small cell lung cancer cells. PLoS One. 2015; 10:e0119379. doi: 10.1371/journal.pone.0119379.

29. Wang LT, Liou JP, Li YH, Liu YM, Pan SL, Teng CM. A novel class I HDAC inhibitor, MPT0G030, induces cell apoptosis and differentiation in human colorectal cancer cells via HDAC1/PKCdelta and E-cadherin. Oncotarget. 2014; 5:5651-62. doi: 10.18632/oncotarget.2155.

30. Chen MY, Liao WS, Lu Z, Bornmann WG, Hennessey V, Washington MN, Rosner GL, Yu Y, Ahmed AA, Bast RC, Jr. Decitabine and suberoylanilide hydroxamic acid (SAHA) inhibit growth of ovarian cancer cell lines and xenografts while inducing expression of imprinted tumor suppressor genes, apoptosis, G2/M arrest, and autophagy. Cancer. 2011; 117:4424-38. doi: 10.1002/cncr.26073.

31. Du L, Risinger AL, King JB, Powell DR, Cichewicz RH. A potent HDAC inhibitor, 1-alaninechlamydocin, from a Tolypocladium sp. induces G2/M cell cycle arrest and apoptosis in MIA PaCa-2 cells. J Nat Prod. 2014; 77:1753-7. doi: 10.1021/np500387h.
32. Fulda S, Debatin KM. Extrinsic versus intrinsic apoptosis pathways in anticancer chemotherapy. Oncogene. 2006; 25:4798-811. doi: 10.1038/sj.onc.1209608.

33. Rivera-Del Valle N, Gao S, Miller CP, Fulbright J, Gonzales C, Sirisawad M, Steggerda S, Wheler J, Balasubramanian S, Chandra J. PCI-24781, a Novel Hydroxamic Acid HDAC Inhibitor, Exerts Cytotoxicity and Histone Alterations via Caspase- 8 and FADD in Leukemia Cells. Int J Cell Biol. 2010; 2010:207420. doi: 10.1155/2010/207420.

34. Hurwitz JL, Stasik I, Kerr EM, Holohan C, Redmond KM, McLaughlin KM, Busacca S, Barbone D, Broaddus VC, Gray SG, O'Byrne KJ, Johnston PG, Fennell DA, et al. Vorinostat/SAHA-induced apoptosis in malignant mesothelioma is FLIP/caspase 8-dependent and HR23Bindependent. Eur J Cancer. 2012; 48:1096-107. doi: 10.1016/j.ejca.2011.11.009.

35. Matthews GM, Newbold A, Johnstone RW. Intrinsic and extrinsic apoptotic pathway signaling as determinants of histone deacetylase inhibitor antitumor activity. Adv Cancer Res. 2012; 116:165-97. doi: 10.1016/B978-0-12-3943873.00005-7.

36. Aggarwal BB, Gupta SC, Kim JH. Historical perspectives on tumor necrosis factor and its superfamily: 25 years later, a golden journey. Blood. 2012; 119:651-65. doi: 10.1182/ blood-2011-04-325225.

37. Pathil A, Armeanu S, Venturelli S, Mascagni P, Weiss TS, Gregor M, Lauer UM, Bitzer M. HDAC inhibitor treatment of hepatoma cells induces both TRAIL-independent apoptosis and restoration of sensitivity to TRAIL. Hepatology. 2006; 43:425-34. doi: 10.1002/hep.21054.

38. Sutheesophon K, Nishimura N, Kobayashi Y, Furukawa Y, Kawano M, Itoh K, Kano Y, Ishii H. Involvement of the tumor necrosis factor (TNF)/TNF receptor system in leukemic cell apoptosis induced by histone deacetylase inhibitor depsipeptide (FK228). J Cell Physiol. 2005; 203:387-97. doi: 10.1002/jcp.20235.

39. Imre G, Gekeler V, Leja A, Beckers T, Boehm M. Histone deacetylase inhibitors suppress the inducibility of nuclear factor-kappaB by tumor necrosis factor-alpha receptor-1 down-regulation. Cancer Res. 2006; 66:5409-18. doi: 10.1158/0008-5472.CAN-05-4225. 